\title{
Anti-TNF-Alpha Therapy for Concomitant Behçet's Disease and Ankylosing Spondylitis
}

\author{
Behçet Hastalığı ile Ankilozan Spondilit Birlikteliğinde Anti-TNF-Alfa Tedavisi
}

\author{
Mustafa ÖZŞAHİN, ${ }^{1}$ Hakan TURAN, ${ }^{2}$ Safinaz ATAOĞLU, ${ }^{1}$ Ali Erdem BAKİ, ${ }^{1}$ Esra ÇELEBİ ${ }^{1}$ \\ ${ }^{1}$ Department of Physical Medicine and Rehabilitation, Medical Faculty of Düzce University, Düzce, Turkey; \\ ${ }^{2}$ Department of Dermatology, Medical Faculty of Düzce University, Düzce, Turkey
}

We have read the manuscript titled "Coexistence of Behçet's Disease (BD) and Ankylosing Spondylitis" authored by Çelik et al. ${ }^{[1]}$ and would like to share our opinions and experience with regard to the subject matter and content of this paper.

A 31-year-old male patient presented at our outpatient clinic with an increase in lumbar and back pain, bilateral pain of the knees with swelling of the left knee, and rashes on both the upper and lower extremities. At the age of 21, while the patient was performing compulsory military service, he complained of lumbar and rare hip pains as well as morning stiffness that lasted for about 30 minutes, and ankylosing spondylitis (AS) was diagnosed. At 24 years of age, the patient experienced swelling of both knees along with difficulty walking and was treated with sulfasalazine and non-steroidal anti-inflammatory drugs (NSAIDs). This treatment regimen was stopped when the patient reached 28 years of age, at which point etanercept was started to alleviate the increased lumbar and back pain and the development of arthritis in both knees. He continued receiving etanercept for two years and, as his condition improved, the patient decided to end the treatment on his own. He has been taking NSAIDs as required for the past seven months.

The patient's lumbar and back pain has increased significantly in the last four months. It has been especially severe in the morning, and the patient has experienced morning stiffness lasting for at least two hours. His complaints have increased with rest and decreased with exercise and physical activity. Although he has complained of fatigue, the patient has not had a fever, night pain, or weight loss. While he has not had any symptoms in the eyes, chest, or heels, he has had bilateral knee pain for the last month, with swelling of the left knee.

During the physical examination of the patient, lumbar lordosis was loss with the increase in dorsal kyphosis. The Schober's test measurement was $2 \mathrm{~cm}$, chest expansion was $2.5 \mathrm{~cm}$, and lumbar spinal motions were limited in all directions. He had no cervical pain or complaints, and his range of joint motion was normal. The sacral compression, Gaenslen's, Mennell's and Patrick's tests were positive. The straight leg extension test and neurological examinations were completely normal. The patient had bilateral effusion of the knees, which was significant on the left side. Also, both knees were warm and painful with compression or movement.

In the laboratory tests, the erythrocyte sedimentation rate (ESR) was found to be $66 \mathrm{~mm} / \mathrm{h}$, the C-reactive protein (CRP) was $14 \mathrm{mg} / \mathrm{L}$ (normal 0.1-0.5), and the rheumatoid factor (RF) was negative. The patient was human leukocyte antigen (HLA)-B27 positive. Anteroposterior pelvis radiographs showed grade III bilateral sacroiliitis,

Received: November 10, 2011 Accepted: February 28, 2012

Correspondence: Mustafa Özşahin, M.D. Düzce Üniversitesi Tıp Fakültesi Fizik Tedavi ve Rehabilitasyon Anabilim Dalı, 81620 Düzce, Turkey.

Tel: +90 380 - 5421416 e-mail: drozsahin@hotmail.com

(02012 Turkish League Against Rheumatism. All rights reserved. 
and lateral lumbar radiographs revealed a decrease in lordosis, squaring of the vertebral bodies, and syndesmophyte formation.

A dermatology consultation was requested for the rashes, and the dermatologist reported several oral lesions associated with aphthous stomatitis which were noted to have appeared repeatedly (4 or 5 times per month) over a four-year period. In addition, erythema nodosum and papulopustular lesions were detected. A typical genital ulcer history, which had appeared only once 15 years previously, was also obtained from the patient. The skin lesions had been particularly active in the past six months. Moreover, the patient had a previous diagnosis of uveitis, and a pathergy test was positive. In light of these results and based on the criteria set by the International Study Group for Behçet's Disease (BD), the patient was diagnosed as having $\mathrm{BD} .^{[2]}$ The lesions of the patient improved after treatment with colchicine $(0.5 \mathrm{mg} 3 \times 1)$ and methylprednisolone (16 $\mathrm{mg} /$ day). In addition, the patient was diagnosed as having uveitis from an ocular examination which followed complaints of stinging, pain, and blurriness in the left eye, and appropriate treatment was initiated.

The Bath Ankylosing Spondylitis Activity Index (BASDAI) is the most widely used instrument for assessing disease activity in patients with $\mathrm{AS}^{[3]}$ It is easy to use, reliable, valid, comprehensive, and sensitive to change. It has been translated from the original English into several other languages, including Turkish. ${ }^{[4]}$ The Assessments in Ankylosing Spondylitis (ASAS) International working group consensus statement proposed using the BASDAI to evaluate active disease in AS patients before the beginning of anti-TNF-alpha $(\alpha)$ therapy. ${ }^{[5]}$ The patient was not being followed up in our hospital; therefore, we had no records of the BASDAI scores either before the start of therapy, or after he gave up the therapy on his own seven months ago. However, seven months before admission to our polyclinic, he had no complaints and stopped the anti-TNF- $\alpha$ therapy, which suggests that the therapy provided an obvious benefit.

Although it is the subject of a long-running debate, $\mathrm{BD}$ is not currently included in the seronegative spondyloarthropathy group. The combination of AS and BD in a single patient has been reported in only a few case presentations in the literature. ${ }^{[6]}$ Therapy for chronic diseases is difficult, and patient satisfaction is for the most part poor. For a patient who has more than one chronic disease, therapy is complicated in terms of drug interactions and side effects. The use of anti-TNF- $\alpha$ agents is preferred for patients who are refractory to treatment with NSAIDs and sulfasalazine for $A S{ }^{[5]}$ In addition, anti-TNF- $\alpha$ agents have been shown to be effective with regard to the mucocutaneous manifestations of BD and inflammatory eye disease in selected patients. ${ }^{[7-9]}$ This data suggests that a patient with both AS and $\mathrm{BD}$ association can be treated by anti-TNF- $\alpha$ therapy. In this respect, Yildız et al. ${ }^{[10]}$ reported positive results with adalimumab therapy in a patient with both AS and BD. In the present case, when the patient stopped etanercept treatment, there were increases in the frequencies of oral aphthae and erythema nodosum related to $\mathrm{BD}$ together with the emergence of uveitis. This suggests that the anti-TNF- $\alpha$ therapy suppressed the mucocutaneous manifestations of BD and inflammatory eye disease. Moreover, this case indicates that anti-TNF- $\alpha$ therapy results in delayed diagnosis of comorbidities due to the suppression of symptoms by the immunosuppressive therapy.

\section{Declaration of conflicting interests}

The authors declared no conflicts of interest with respect to the authorship and/or publication of this article.

\section{Funding}

The authors received no financial support for the research and/or authorship of this article.

\section{REFERENCES}

1. Çelik C, Uçan H, Uçkun AC, Alemdaroğlu E. Coexistence of Behçet's disease and ankylosing spondylitis. Turk J Rheumatol 2011;26:271-2.

2. Criteria for diagnosis of Behçet's disease. International Study Group for Behçet's Disease. Lancet 1990;335:1078-80.

3. Garrett S, Jenkinson T, Kennedy LG, Whitelock H, Gaisford P, Calin A. A new approach to defining disease status in ankylosing spondylitis: the Bath Ankylosing Spondylitis Disease Activity Index. J Rheumatol 1994;21:2286-91.

4. Akkoc Y, Karatepe AG, Akar S, Kirazli Y, Akkoc N. A Turkish version of the Bath Ankylosing Spondylitis Disease Activity Index: reliability and validity. Rheumatol Int 2005;25:280-4.

5. Braun J, Pham T, Sieper J, Davis J, van der Linden $S$, Dougados $M$, et al. International ASAS consensus statement for the use of anti-tumour necrosis factor agents in patients with ankylosing spondylitis. Ann Rheum Dis 2003;62:817-24.

6. Borman P, Bodur H, Ak G, Bostan EE, Barça N. The coexistence of Behçet's disease and ankylosing spondylitis. Rheumatol Int 2000;19:195-8. 
7. van Laar JA, Missotten T, van Daele PL, Jamnitski A, Baarsma GS, van Hagen PM. Adalimumab: a new modality for Behçet's disease? Ann Rheum Dis 2007;66:565-6.

8. Sfikakis PP, Markomichelakis N, Alpsoy E, Assaad-Khalil S, Bodaghi B, Gul A, et al. Anti-TNF therapy in the management of Behcet's disease-review and basis for recommendations. Rheumatology (Oxford) 2007;46:736-41.
9. Lindstedt EW, Baarsma GS, Kuijpers RW, van Hagen PM. Anti-TNF-alpha therapy for sight threatening uveitis. Br J Ophthalmol 2005;89:533-6.

10. Yildiz N, Alkan H, Ardic F, Topuz O. Successful treatment with adalimumab in a patient with coexisting Behçet's disease and ankylosing spondylitis. Rheumatol Int 2010;30:1511-4. 